УДК 664.78 .03 https://doi.org/10.35546/kntu2078-4481.2021.4.15

О.Я. СЕМЕШКО

Херсонський національний технічний університет ORCID: 0000-0002-8309-5273

М.Л. КУЛІГІН

Херсонський національний технічний університет ORCID: 0000-0002-7678-2841

I.В. ГОРОВИЙ

Херсонський національний технічний університет ORCID:0000-0003-0811-9746

\title{
ТЕХНОЛОГІЧНА ЕКСПЕРТИЗА КОНСЕРВОВАНОЇ КУКУРУДЗИ
}

Виробництво консервів тісно пов'язане із розвитком агропромислового комплексу та потребує постійної і неослабної уваги, як виробництво, яке відрізняється різноманітністю сировини, безліччю технологічних проиесів та їх параметрів. В Україні питома вага плодоовочеконсервної промисловості за обсягом реалізованої продукиії, чисельністю праџюючих та вартістю основних засобів становить значну частку в промисловому комплексі краӥни. Продукція иієё підгалузі забезпечує населення високовітамінізованим та оздоровлюючим харчуванням, оскільки ї̈ одержують із природної сировини. Зважаючи на те, щзо вживання у їжу свіжих фруктів, овочів та ягід обмежується сезонністю $i$ територіальними відмінностями природних умов, консервування дозволяє забезпечити їх споживання у будь-який період року.

Кукурудза в усьому світі вважається однією з основних кормових і харчових злакових культур. Особливим попитом користується иукрова кукурудза, яка в консервованому вигляді являє собою смачний $i$ поживний делікатес. Для забезпечення високих смакових характеристик та мікробіологічних показників консервів з иукрової кукурудзи необхідним с суворий контроль якості сировини та готової продукиії, а також неухильне дотримання технології ї̈ виробництва.

Мета роботи полягала у проведенні заключного етапу технологічної експертизи харчової продукиії - експертизи якісного та кількісного складу консервованої кукурудзи виробництва торгових марок «Щедрий Пан», «RIO», «Гурман» та «Чумак». ДСТУ 7164:2010 «Кукурудза иукрова консервована. Технічні умови» було здійснено органолептичну оиінку досліджуваних зразків консервів та перевірено їх фізико-хімічні характеристики, а саме масову частку зерен від маси нетто консервів, вказаної на етикетиі, та масову частку хлоридів.

В результаті проведених досліджень встановлено зразок консервованої кукурудзи, який за органолептичними показниками - запахом, кольором, смаком, зовнішнім виглядом, иілісністю зерен, кольором заливи - має найвищі показники. Отримані результати дослідження масової частки зерен від маси нетто консервів, вказаної на етикетиі, та масової частки хлоридів дозволили встановити зразки консервів, які відповідають вимогам, щзо регламентовані нормативною документацією.

Ключові слова: кукурудза, консервування, органолептичні показники, вміст хлоридів, технологічна експертиза.

О.Я. СЕМЕШКО

Херсонский национальный технический университет

ORCID: 0000-0002-8309-5273

М.Л. КУЛИГИН

Херсонский национальный технический университет

ORCID: 0000-0002-7678-2841

И.В. ГОРОВЫЙ

Херсонский национальный технический университет

ORCID:0000-0003-0811-9746

\section{ТЕХНОЛОГИЧЕСКАЯ ЭКСПЕРТИЗА КОНСЕРВИРОВАННОЙ КУКУРУЗЫ}

Производство консервов тесно связано с развитием агропромышленного комплекса и требует постоянного и неослабевающего внимания, как производство, отличающееся разнообразием сырья, множеством технологических процессов $u$ ux параметров. В Украине удельный вес плодоовощеконсервной промышленности по объему реализованной продукиии, численности работающих и стоимости основных средств составляет значительную долю в промышленном комплексе страны. Продукиия этой подотрасли обеспечивает население высоковитаминизированньм и оздоровительным питанием, поскольку его получают из природного сырья. Учитывая, что употребление в пищу свежих 
фруктов, овощей и ягод ограничивается сезонностью и территориальными отличиями природных условий, консервирование позволяет обеспечить их потребление в любое время года.

Кукуруза во всем мире считается одной из основных кормовых и пищевых злаковых культур. Особым спросом пользуется сахарная кукуруза, которая в консервированном виде являет собой вкусный и питательный деликатес. Для обеспечения высоких вкусовых характеристик и микробиологических показателей консервов из сахарной кукурузы необходим строгий контроль качества сырья и готовой продукиии, а также неукоснительное соблюдение технологии ее производства.

Цель работы заключалась в проведении заключительного этапа технологической экспертизы пищевой продукции - экспертизы качественного и количественного состава консервированной кукурузы производства торговых марок «Щедрый Пан», «RIO», «Гурман» и «Чумак». Согласно ДСТУ 7164:2010 «Кукуруза сахарная консервированная. Технические условия» была проведена органолептическая оценка исследуемых образиов консервов и проверены их физико-химические характеристики, а именно массовая доля зерен от массы нетто консервов, указанной на этикетке, и массовая доля хлоридов.

В результате проведенных исследований установлен образеи консервированной кукурузы, который по органолептическим показателям - запаху, ивету, вкусу, внешнему виду, иелостности зерен, ивету заливы - имеет самые высокие показатели. Полученные результаты исследования массовой доли зерен от массы нетто консервов, указанной на этикетке, и массовой доли хлоридов позволили установить образиьь консервов, отвечающче требованиям, регламентируемым нормативной документаичей.

Ключевые слова: кукуруза, консервирование, органолептические показатели, содержание хлоридов, технологчческая экспертиза.

O.Ya. SEMESHKO

Kherson National Technical University ORCID: 0000-0002-8309-5273

M.L. KULIGIN

Kherson National Technical University ORCID: 0000-0002-7678-2841

I.V. GOROVYI

Kherson National Technical University ORCID:0000-0003-0811-9746

\section{TECHNOLOGICAL EXPERTISE OF CANNED CORN}

The production of canned food is closely related to the development of the agro-industrial complex and requires constant and unflagging attention, as a production characterized by a variety of raw materials, many technological processes and their parameters. In Ukraine, the share of the fruit and vegetable canning industry in terms of the volume of products sold, the number of employees and the cost of fixed assets constitutes a significant part in the country's industrial complex. The products of this sub-industry provide the population with highly vitaminized and health-improving food, since it is obtained from natural raw materials. Considering that the consumption of fresh fruits, vegetables and berries in food is limited by seasonality and territorial differences in natural conditions, canning allows you to ensure their consumption at any time of the year.

All over the world, corn is considered one of the main forage and food crops. Sweet corn is in great demand, which, when canned, is a delicious and nutritious delicacy. To ensure high taste characteristics and microbiological indicators of canned sugar corn, strict quality control of raw materials and finished products is required, as well as strict adherence to the technology of its production.

The purpose of the work was to carry out the final stage of the technological examination of food products - an examination of the qualitative and quantitative composition of canned corn produced by the brands "Schedry Pan", "RIO", "Gurman" and "Chumak". According to DSTU 7164: 2010 "Canned sugar corn. Specifications" organoleptic assessment of the studied canned food samples was carried out and their physicochemical characteristics were checked, namely, the mass fraction of grains from the net weight of canned food indicated on the label, and the mass fraction of chlorides.

As a result of the research carried out, a sample of canned corn was established, which has the highest rating in terms of organoleptic characteristics - smell, colour, taste, appearance, grain integrity, and colour of the pouring. The obtained results of the study of the mass fraction of grains from the net mass of canned food indicated on the label and the mass fraction of chlorides made it possible to establish canned food samples that meet the requirements regulated by the standard documentation.

Keywords: corn, canning, organoleptic characteristics, chlorides content, technological expertise. 


\section{Постановка проблеми}

На сьогодні в Україні відсутній чіткий системний підхід щодо розробки стратегії економічного розвитку харчової промисловості. Необхідно зазначити, що плодоовочева консервна промисловість потребує постійної і неослабної уваги, як виробництво, яке відрізняється різноманітністю сировини, безліччю технологічних процесів та їх параметрів. До того ж виробництво консервів тісно пов'язане із розвитком агропромислового комплексу в цілому, адже залежить від якості та наявності сільськогосподарської сировини [1].

В Україні плодоовочеконсервна промисловість в багатьох областях має профілююче значення. За обсягом реалізованої продукції, чисельністю працюючих та вартістю основних засобів їх питома вага в промисловому комплексі країни становила у 2018 р. відповідно 15,5, 14,6 та 5,2 \% [2]. Продукція цієї підгалузі забезпечує населення високовітамінізованим, оздоровлюючим харчуванням, адже ії сировину одержують безпосередньо із самої природи. Фрукти, овочі та ягоди є важливим джерелом вуглеводів, органічних кислот, мінеральних солей і вітамінів, але їх споживання у свіжому вигляді обмежується через сезонність і територіальні відмінності природних умов. Тому консервування дозволяє забезпечити їх споживання у міжсезонний період. Особливо це $є$ важливим для західних та північних регіонів країни [1].

Сьогодні кукурудза користується попитом в усьому світі і вважається однією з основних кормових злакових культур і харчових злаків. Свіжа кукурудза є поживним продуктом, повільно перетравлюється і дає тривале відчуття ситості, хоча і має невисоку калорійність. В цілому вигляді зерна використовуються в якості гарнірів до м'яса і в овочевих салатах, а в подрібненому стані - для виробництва борошна та крупи, випікання хліба та приготування каш, а 3 деяких сортів робиться повітряний попкорн [3]. Особливим попитом користується десертна (цукрова) кукурудза, яка в свіжому вигляді являє собою окрему страву, а в консервованому представляє смачний і поживний делікатес. Зважаючи на популярність серед споживачів консерви з цукрової кукурудзи для забезпечення їх високих смакових характеристик та мікробіологічних показників необхідним є суворий контроль якості сировини та готової продукції, а також неухильне дотримання технології ії виробництва.

\section{Аналіз останніх досліджень і публікацій}

У консервуванні використовують спеціальні сорти кукурудзи та збирають їі на стадії консервної або молочної стиглості. Саме в цей час зерна кукурудзи ніжні, соковиті і містять найбільшу кількість цукрів. Забирають кукурудзу в 2-3 прийоми, по мірі достигання качанів, які перед консервуванням повинні бути свіжі, стиглі, правильної циліндричної або незначною конусоподібної форми, вкриті зеленим листям 3 темно-коричневими нитками, що починають сохнути. При цьому зерно має бути гладеньким, налитим і при натисканні має виділяти сік молочного кольору з солодким смаком [4].

Переважно консерви з цукрової кукурудзи виробляють 3 цілих зерен. Після очищення качанів від оболонки, мийки і інспекції їх сортують і відбирають качани правильної форми, які повністю заповнені неушкодженими зернами $[4,5]$. Далі кукурудзу очищають від оболонки на спеціальних обдирні машинах. При цьому видаляють листя і шовковисті нитки, обрізають плодоніжки. Кількість відходів становить $30-35 \%$. Потім кукурудзу миють в барабанній конічній мийній або в душовій мийній машині при тиску води 2-3 атм. Під час інспекції на конвеєрі видаляють листя, що залишилось, качани 3 дефектами, обрізають кінці, відбраковують уражені шкідниками качани і сортують за придатністю для виробництва консервів з цілих зерен і з подрібнених $[4,5]$. Качани спочатку бланшують в безперервно діючих бланшувачах протягом 2-3 хв. при температурі води 85-90 і швидко охолоджують холодною водою. Під час бланшування відбувається ущільнення клітин зерен, коагуляція білкових речовин, набрякання і клейстеризація крохмалю, що є дуже важливим, оскільки сприяє зниженню втрат розчинних речовин під час подальшого охолодження водою. Після бланшування зерна кукурудзи зрізають на спеціальних машинах з качанів, при цьому досягають регулювання положення ножів так, щоб зерна зрізались повністю. Зазвичай вихід зрізаних зерен складає 23-25\% від ваги неочищених качанів. Далі зерна миють і очищають на спеціальній машині барабанного типу з метою видалення будьяких залишків листя, стержнів, ниток тощо. Після миття ще раз інспектують зерна на стрічковому транспортері. При цьому видаляють неоднорідні за кольором зерна, а також домішки, що можуть залишитись після миття. Підготовлені банки наповнюють кукурудзою та розсолом на автоматичному наповнювачі в співвідношенні $60-65 \%$ зерен і $35-40 \%$ розсолу. При цьому зазвичай розсіл містить 2,5-3\% кухонної солі і надходити в банку гарячим при температурі $85-90^{\circ} \mathrm{C}$. Далі банки негайно закупорюють на вакуум-закочувальній машині і стерилізують. Консервовану кукурудзу зазвичай готують в жерстяних банках внаслідок того, що продукт містить значну кількість крохмалю. Він ускладнює конвекцію рідкої частини консервів при стерилізації, тому для поліпшення теплопередачі і доцільно застосовувати бляшану тару. Теплопередача покращується і прискорюється при стерилізації у безперервно діючих апаратах, у яких банки обертаються $[4,5]$.

Кукурудза не втрачає смакові властивості при консервації і залишається свіжою, пружною i ніжно-солодкою, що є безперечною перевагою цього продукту. Трохи змінюється хімічний склад: вдвічі 
скорочується зміст магнію, фосфору і калію, зате в 10 разів зростає кількість натрію. При цьому слід зазначити, що «втрати» корисних і лікувальних властивостей кукурудзи при консервуванні на порядок менші, ніж у горошку або квасолі.

Консервована кукурудза також містить багато білка і вуглеводів, клітковини і вітамінів. Вона нормалізує роботу шлунково-кишкового тракту, серцево-судинної системи і обмін речовин, знижує загрозу онкологічних захворювань i атеросклерозу, володіє антистресовими i антиоксидантними властивостями, зміцнює імунітет і надає омолоджуючого ефекту, заспокоює нервову систему і підвищує розумову активність, знижує рівень «поганого» холестерину і цукру в крові та виводить токсини 3 організму [3].

Однак консервована кукурудза внаслідок використання сировини низької якості, а також недотримання технологічного регламенту виробництва може мати дефекти. Насамперед це наявність пошкоджених зерен та домішок рослинного походження (шматочки качанів, частинки листяного покриву, шовковисті нитки), мутність заливи тощо. Таким чином, з огляду на вищезазначене, актуальним $\epsilon$ проведення технологічної експертизи та оцінки якості кукурудзи консервованої.

Формулювання мети дослідження

Мета роботи - технологічна експертиза та оцінка якості кукурудзи консервованої з метою виробництва високоякісного та безпечного продукту.

\section{Викладення основного матеріалу дослідження}

Як об’ єкт дослідження у роботі обрано 4 зразки консервованої кукурудзи, що виробляються за ДСТУ 7164:2010 «Кукурудза цукрова консервована. Технічні умови» [6] різними торговими марками, а саме: «Щедрий Пан», «RIO», «Гурман» та «Чумак». Досліджуванні зразки консервів представлені на рис. 1 .

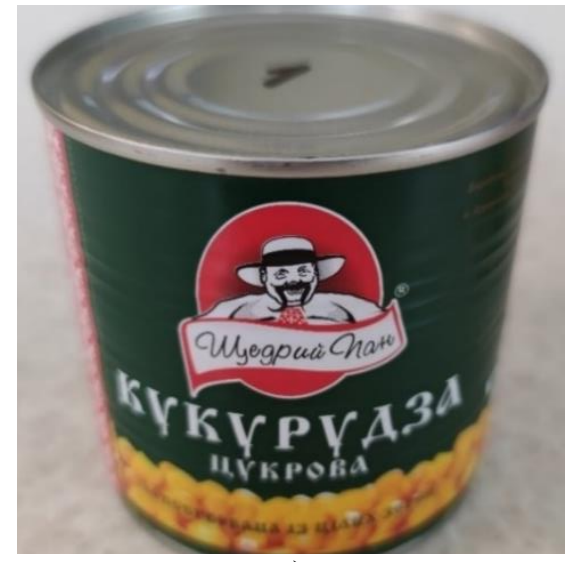

a)

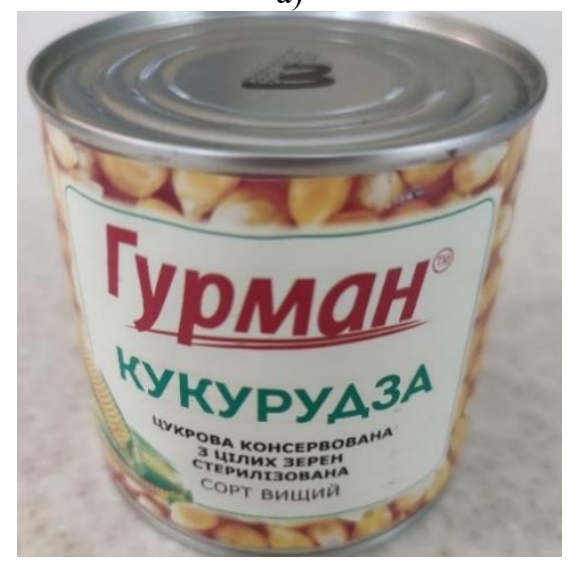

B)

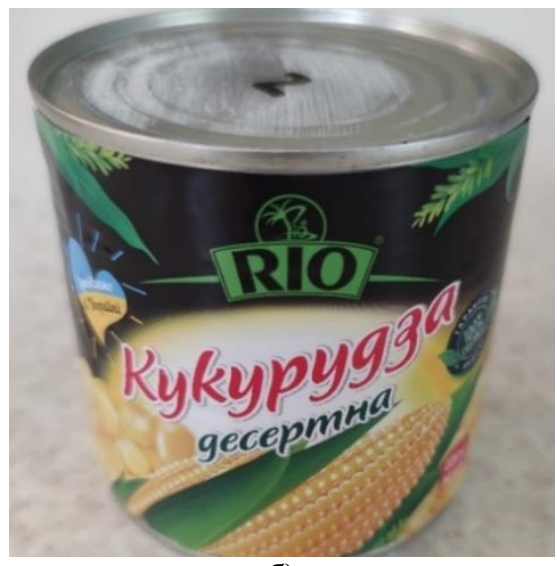

б)

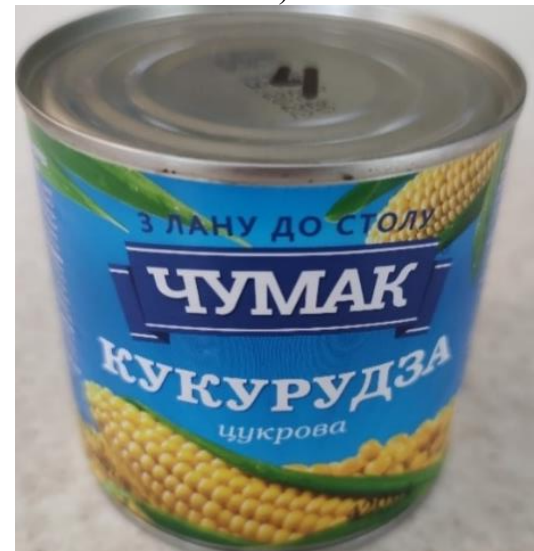

г)

Рис. 1. Досліджуванні зразки кукурудзи консервованої: а) TM «Щедрий Пан»; б) TM «RIO»; в) TM «Гурман»; г) ТМ «Чумак».

За інформацією на етикетках обрані консерви - це кукурудза цукрова консервована 3 цільних зерен. Зразки виробництва ТМ «Щедрий Пан», ТМ «Гурман», ТМ «Чумак» - вищого сорту, зразок виробництва TM «RIO» - першого сорту. Склад консервів наступний: зерна кукурудзи цукрової, вода питна, цукор білий, кухонна сіль.

Дослідження органолептичних показників консервованої кукурудзи проводили за чинним ДСТУ та методом оцінювання у балах за розробленою шкалою. За ДСТУ 7164:2010 «Кукурудза цукрова 
консервована. Технічні умови» проводилось визначенням наступних показників: зовнішній вигляд, наявність механічних пошкоджень, смак i запах, колір. Також було проведено оцінку якості консервованої кукурудзи у балах шляхом застосування 5 -ти бальної шкали. При цьому 5 балів - це найвища оцінка, а 1 бал - найнижча. Оцінку якості консервованої кукурудзи здійснювали при опитуванні 5-ти респондентів за наступними показниками консервованої кукурудзи: запах, колір, смак, зовнішній вигляд, цілісність зерен, колір заливи.

Серед фізико-хімічних показників консервованої кукурудзи було визначено масову частку зерен до маси нетто консервів та масову частку хлоридів.

Визначення масової частки зерен до маси нетто консервів проводили згідно з ГОСТ 8756.1-2017 [7]. Масову частку зерен М, \%, від зазначеної на етикетці маси нетто продукту обчислюють за формулою:

$$
\mathrm{M}=\frac{m_{i}}{m} 100,
$$

де

$\mathrm{m}_{\mathrm{i}}-$ маса зерен у банці, г;

m - маса нетто, г, яка розраховується за формулою (2):

$$
m=m_{2}-m_{1},
$$

де $\mathrm{m}_{2}-$ маса упаковки 3 продуктом, г

$\mathrm{m}_{1}$ - маса порожньої упаковки, г.

За остаточний результат приймають середньоарифметичне значення результатів вимірювань, округлене $з$ точністю до першого десяткового знаку. Результати обчислення порівнюють з відхиленнями, що допускаються складу, зазначеними в документах на конкретні види продуктів.

Визначення масової частки хлоридів здійснюють відповідно до вимог ГОСТ 26186 [8] аргентометричним методом за Мором. Метод заснований на титруванні водної витяжки досліджуваного продукту після нейтралізації титрованим розчином азотнокислого срібла в присутності хромовокислого калію як індикатора. Наважку кукурудзи подрібнювали за допомогою ступки до отримання гомогенної маси. 3 підготовленої проби продукту в хімічний стакан беруть наважку масою від 10 до 25 г і кількісно переносять ii $100 \mathrm{~cm}^{3}$ гарячої води в мірну колбу місткістю $250 \mathrm{~cm}^{3}$. Суміш, періодично збовтуючи, нагрівають протягом 15 хв. на водяній бані. Після охолодження до кімнатної температури об'єм вмісту колби доводять водою до мітки і фільтрують через паперовий складчастий фільтр. $20 \mathrm{~cm}^{3}$ отриманого фільтрату відбирають піпеткою в конічну колбу і в залежності від $\mathrm{pH}$ середовища нейтралізують. Нейтралізацію фільтрату проводили в такий спосіб: в приготований і відміряний в конічну колбу розчин опускають невеликий шматочок лакмусового паперу, потім додають на кінчику шпателя кілька кристалів кислого вуглекислого калію до появи синього забарвлення лакмусового паперу. Надлишок кислого вуглекислого калію не впливає на результати аналізу. Після припинення виділення бульбашок в розчині в витяжку додають $1 \mathrm{~cm}^{3}$ розчину хромовокислого калію і титрують розчином азотнокислого срібла до появи цегляно-червоного забарвлення. Масову частку хлоридів X, \%, в перерахунку на хлористий натрій, обчислюють за формулою:

$$
\mathrm{M}=\frac{V M c}{m} \frac{V_{1}}{V_{2}} 0,1,
$$

де $\mathrm{V}$ - обсяг титрованого розчину азотнокислого срібла, витрачений на титрування, $\mathrm{cm}^{3}$;

c - молярна концентрація титрованого розчину азотнокислого срібла, моль/дм³;

М - молярна маса хлористого натрію $(\mathrm{NaCl})=58,45$ г/моль;

$\mathrm{m}$ - маса наважки продукту, г;

$\mathrm{V}_{1}$ - об'єм, до якого доведена водна витяжка наважки продукту, см³

$\mathrm{V}_{2}$ - об'єм фільтрату, взятий для визначення, $\mathrm{cm}^{3}$.

Результати дослідження органолептичних показників кукурудзи консервованої за ДСТУ. Зовнішній вигляд досліджуваних консервів представлено на рис. 2. 


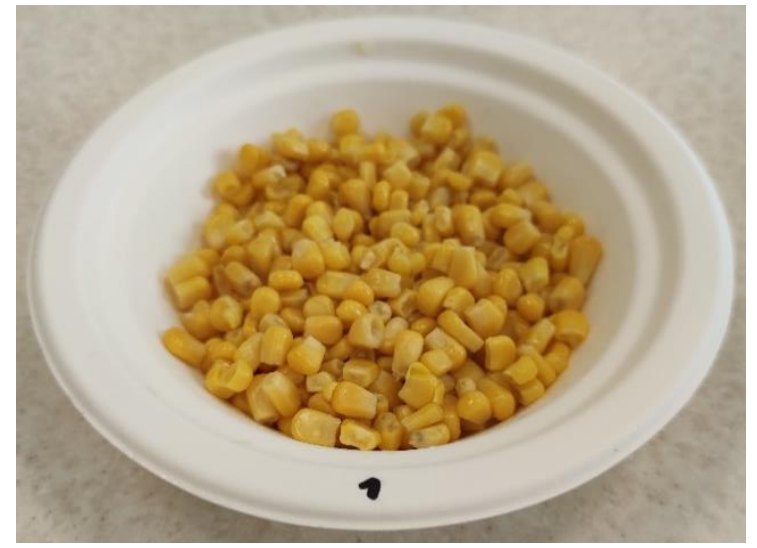

a)

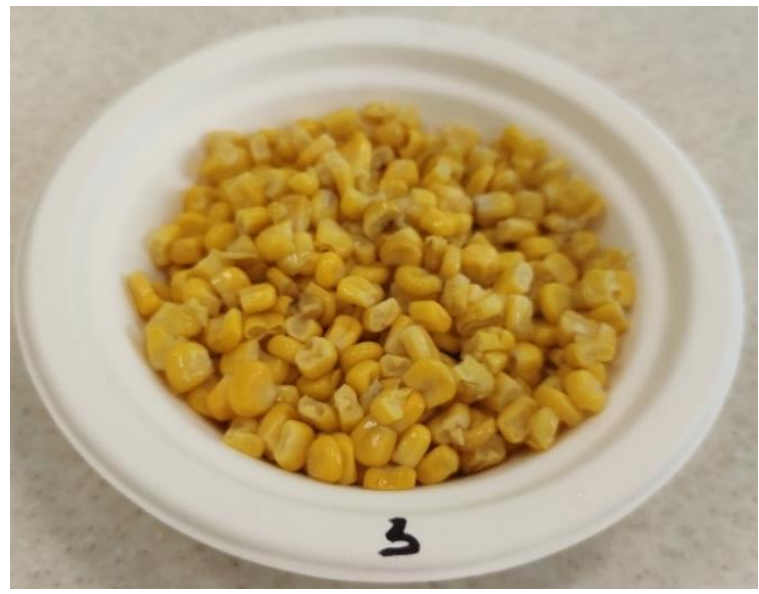

В)

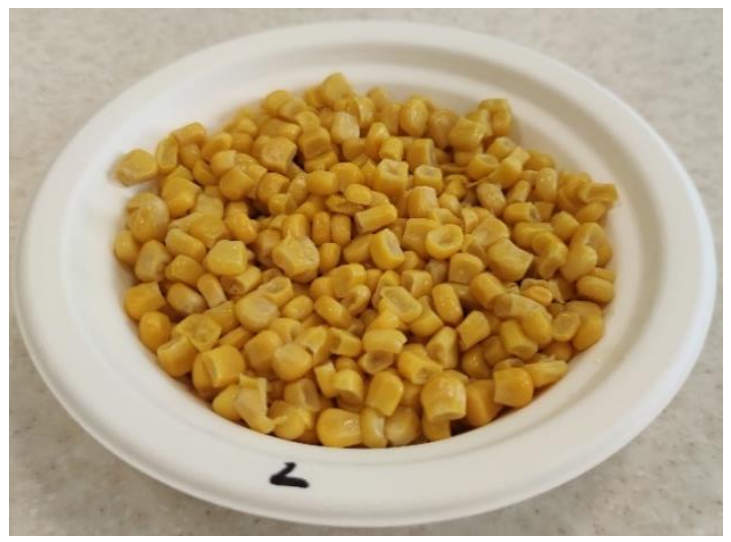

б)

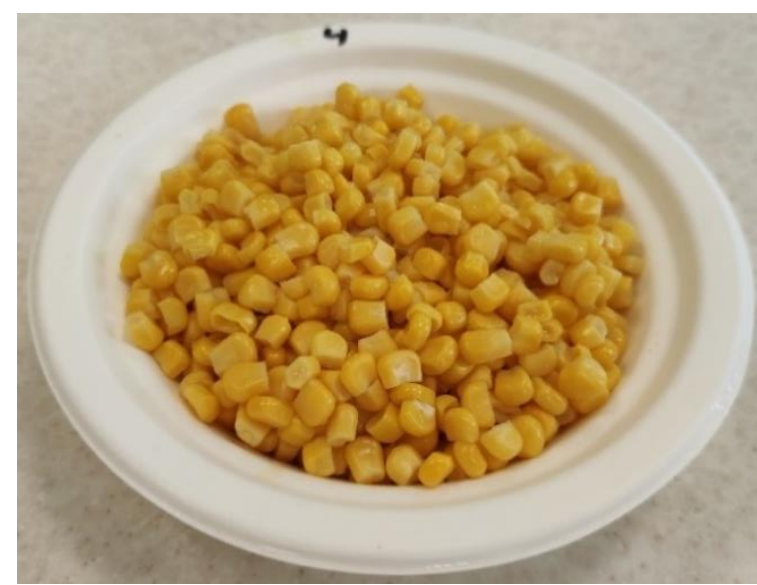

г)

Рис. 2. Зовнішній вигляд зразків кукурудзи консервованої: а) TM «Щедрий Пан»; б) TM «RIO»; в) ТМ «Гурман»; г) ТМ «Чумак».

Органолептичні показники якості кукурудзи консервованої зразків досліджуваних торгових марок наведені у табл. 1.

Органолептичні показники зразків кукурудзи консервованої

Таблиця 1

\begin{tabular}{|c|c|c|c|c|}
\hline Зразок & Зовнішній вигляд & $\begin{array}{c}\text { Наявність } \\
\text { механічно } \\
\text { пошкоджених } \\
\text { зерен в \%, не } \\
\text { більше }\end{array}$ & Смак і запах & Колір \\
\hline 1 & 2 & 3 & 4 & 5 \\
\hline $\begin{array}{c}\text { ДСТУ } \\
\text { 7164:2010 }\end{array}$ & $\begin{array}{c}\text { Зрізані цілі зерна, правильно } \\
\text { зрізані, з однаковою глибиною } \\
\text { зрізування. Без рваних зерен і } \\
\text { зерен з тканиною качана, без } \\
\text { шматочків стрижнів і качанів, } \\
\text { частинок листя і шовковистих } \\
\text { ниток. Заливка молочного } \\
\text { відтінку. }\end{array}$ & $\begin{array}{c}20,0 \text { для } \\
\text { вищого сорту; } \\
40,0 \text { для } \\
\text { першого сорту. }\end{array}$ & $\begin{array}{c}\text { Властиві вареній } \\
\text { кукурудзі у стадії } \\
\text { молочної } \\
\text { стиглості, без } \\
\text { стороннього } \\
\text { присмаку і } \\
\text { запаху. }\end{array}$ & $\begin{array}{c}\text { Білий, золотистий або } \\
\text { жовтий, без наявності зерен } \\
\text { темного кольору, } \\
\text { однорідний в одній банці. } \\
\text { Допускається наявність } \\
\text { одиночних зерен кукурудзи, } \\
\text { які відрізняються за } \\
\text { кольором від основної маси. } \\
\text { Не допускається наявність } \\
\text { плямистих зерен. }\end{array}$ \\
\hline
\end{tabular}




\begin{tabular}{|c|c|c|c|c|}
\hline & & & \multicolumn{2}{|c|}{ Продовження табл. 1} \\
\hline 1 & 2 & 3 & 4 & 5 \\
\hline $\begin{array}{c}\text { TM } \\
\text { «Щедрий } \\
\text { Пан» }\end{array}$ & $\begin{array}{c}\text { Зрізані цілі зерна, правильно } \\
\text { зрізані, з однаковою } \\
\text { глибиною зрізування. Без } \\
\text { рваних зерен і зерен з } \\
\text { тканиною качана, без } \\
\text { шматочків стрижнів і качанів, } \\
\text { частинок листя і шовковистих } \\
\text { ниток. Заливка молочного } \\
\text { відтінку. }\end{array}$ & 18,0 & $\begin{array}{c}\text { Властиві вареній } \\
\text { кукурудзі у стадії } \\
\text { молочної стиглості, без } \\
\text { стороннього присмаку і } \\
\text { запаху. }\end{array}$ & $\begin{array}{l}\text { Жовтий, без } \\
\text { наявності } \\
\text { зерен темного } \\
\text { кольору, } \\
\text { однорідний в } \\
\text { одній банці. }\end{array}$ \\
\hline $\mathrm{TM} \ll \mathrm{RIO} »$ & $\begin{array}{c}\text { Зрізані цілі зерна, правильно } \\
\text { зрізані, але з різною } \\
\text { глибиною зрізування. Без } \\
\text { рваних зерен і зерен з } \\
\text { тканиною качана, без } \\
\text { шматочків стрижнів і качанів, } \\
\text { частинок листя і шовковистих } \\
\text { ниток. Заливка з легкою } \\
\text { мутністю. } \\
\end{array}$ & 28,0 & $\begin{array}{c}\text { Невиражений, без } \\
\text { стороннього присмаку і } \\
\text { запаху. }\end{array}$ & $\begin{array}{c}\text { Жовтий, із } \\
\text { зернами } \\
\text { темного } \\
\text { кольору, } \\
\text { однорідний в } \\
\text { одній банці. }\end{array}$ \\
\hline $\begin{array}{c}\text { TM } \\
\text { «Гурман» }\end{array}$ & $\begin{array}{c}\text { Зрізані рвані зерна, } \\
\text { неправильно зрізані, з різною } \\
\text { глибиною зрізування. Без } \\
\text { тканини качана, без } \\
\text { шматочків стрижнів і качанів, } \\
\text { частинок листя і шовковистих } \\
\text { ниток. Заливка мутна.. } \\
\end{array}$ & 35,0 & $\begin{array}{c}\text { Не властиві вареній } \\
\text { кукурудзі у стадії } \\
\text { молочної стиглості, } \\
\text { присутні кислий смак і } \\
\text { запах. }\end{array}$ & $\begin{array}{l}\text { Темні зерна, } \\
\text { однорідний в } \\
\text { одній банці. }\end{array}$ \\
\hline ТМ «Чумак» & $\begin{array}{c}\text { Зрізані цілі зерна, правильно } \\
\text { зрізані, з однаковою } \\
\text { глибиною зрізування. Без } \\
\text { рваних зерен і зерен з } \\
\text { тканиною качана, без } \\
\text { шматочків стрижнів і качанів, } \\
\text { частинок листя і шовковистих } \\
\text { ниток. Заливка молочного } \\
\text { відтінку. }\end{array}$ & 12,0 & $\begin{array}{c}\text { Властиві вареній } \\
\text { кукурудзі у стадії } \\
\text { молочної стиглості, без } \\
\text { стороннього присмаку і } \\
\text { запаху. }\end{array}$ & $\begin{array}{l}\text { Золотистий, } \\
\text { без наявності } \\
\text { зерен темного } \\
\text { кольору, } \\
\text { однорідний в } \\
\text { одній банці. }\end{array}$ \\
\hline
\end{tabular}
«Чумак».

За отриманими результатами вимогам ДСТУ повністю відповідає консервована кукурудза ТМ

Результати бальної оцінки якості досліджуваних зразків консервованої кукурудзи представлено у вигляді табл. 2 та діаграми на рис. 3.

Таблиця 2

Бальна оцінка якості зразків консервованої кукурудзи

\begin{tabular}{|c|c|c|c|c|c|c|}
\hline \multirow{3}{*}{ Показник якості } & \multicolumn{5}{|c|}{ 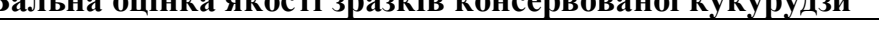 } & \multirow{3}{*}{$\begin{array}{c}\text { Середня } \\
\text { кількість } \\
\text { балів }\end{array}$} \\
\hline & \multicolumn{5}{|c|}{ Дегустаційна оцінка, бал } & \\
\hline & 1 & 2 & 3 & 4 & 5 & \\
\hline 1 & 2 & 3 & 4 & 5 & 6 & 7 \\
\hline \multicolumn{7}{|c|}{ ТМ «Щедрий Пан» } \\
\hline Запах & 5 & 5 & 4 & 5 & 5 & 4,8 \\
\hline Колір & 4 & 4 & 4 & 5 & 4 & 4,2 \\
\hline Смак & 5 & 4 & 4 & 5 & 5 & 4,6 \\
\hline Зовнішній вигляд & 4 & 4 & 4 & 4 & 4 & 4,0 \\
\hline Цілісність зерен & 5 & 4 & 4 & 4 & 4 & 4,2 \\
\hline Колір заливи & 4 & 5 & 5 & 4 & 4 & 4,4 \\
\hline Загальна сума балів & 27 & 26 & 25 & 27 & 26 & 26,2 \\
\hline \multicolumn{7}{|c|}{$\mathrm{TM}\langle\mathrm{RIO} »$} \\
\hline Запах & 3 & 3 & 3 & 3 & 3 & 3,0 \\
\hline Колір & 3 & 3 & 3 & 4 & 3 & 3,2 \\
\hline Смак & 5 & 4 & 4 & 4 & 4 & 4,2 \\
\hline Зовнішній вигляд & 3 & 3 & 4 & 3 & 3 & 3,2 \\
\hline Цілісність зерен & 4 & 3 & 4 & 4 & 3 & 3,6 \\
\hline Колір заливи & 4 & 4 & 4 & 4 & 4 & 4,0 \\
\hline Загальна сума балів & 22 & 20 & 22 & 22 & 20 & 21,2 \\
\hline
\end{tabular}




\begin{tabular}{|c|c|c|c|c|c|c|}
\hline & & & & & \multicolumn{2}{|c|}{ Продовження табл. 2} \\
\hline 1 & 2 & 3 & 4 & 5 & 6 & 7 \\
\hline \multicolumn{7}{|c|}{ TM «Гурман» } \\
\hline Запах & 1 & 1 & 1 & 1 & 1 & 1,0 \\
\hline Колір & 3 & 3 & 3 & 2 & 3 & 2,8 \\
\hline Смак & 1 & 1 & 1 & 1 & 1 & 1,0 \\
\hline Зовнішній вигляд & 2 & 2 & 2 & 3 & 2 & 2,2 \\
\hline Цілісність зерен & 2 & 3 & 3 & 3 & 2 & 2,6 \\
\hline Колір заливи & 3 & 2 & 3 & 2 & 3 & 2,6 \\
\hline Загальна сума балів & 12 & 12 & 13 & 12 & 12 & 12,2 \\
\hline \multicolumn{7}{|c|}{ ТМ «Чумак» } \\
\hline Запах & 5 & 5 & 5 & 5 & 5 & 5,0 \\
\hline Колір & 5 & 5 & 5 & 5 & 5 & 5,0 \\
\hline Смак & 5 & 5 & 5 & 4 & 5 & 4,8 \\
\hline Зовнішній вигляд & 5 & 5 & 5 & 5 & 5 & 5,0 \\
\hline Цілісність зерен & 5 & 5 & 5 & 4 & 5 & 4,8 \\
\hline Колір заливи & 5 & 5 & 5 & 5 & 5 & 5,0 \\
\hline Загальна сума балів & 30 & 30 & 30 & 28 & 30 & 29,6 \\
\hline
\end{tabular}

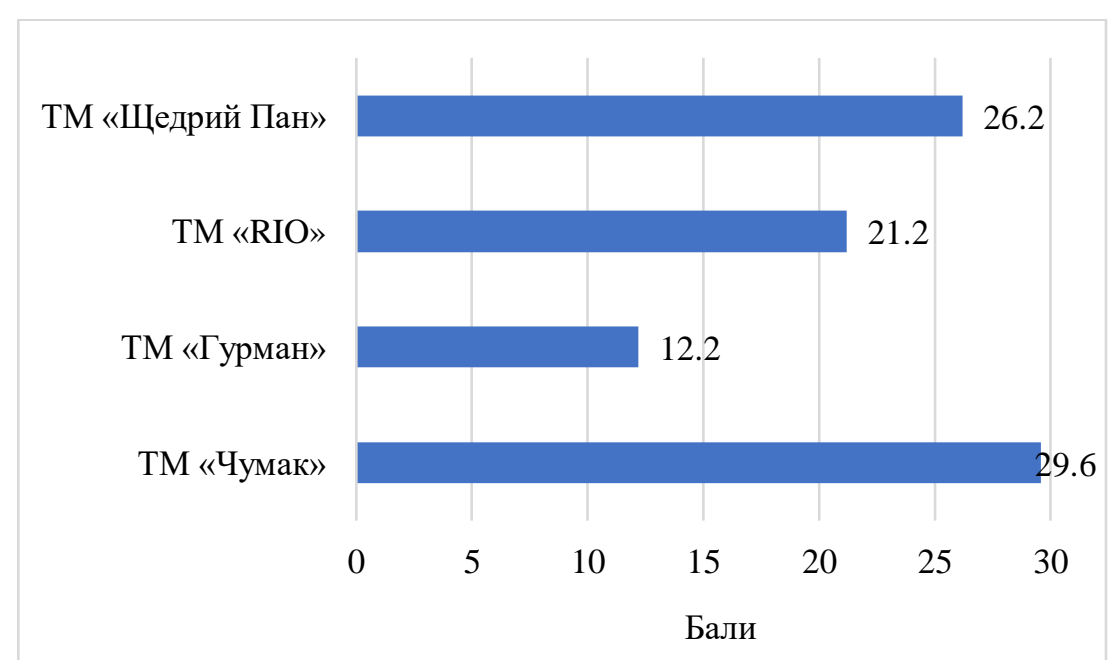

Рис. 3. Порівняльна характеристика якості кукурудзи консервованої за підсумковою бальною оцінкою

За результатами здійсненої органолептичної оцінки якості досліджуваних зразків консервованої кукурудзи, що було проведено за діючим ДСТУ та шляхом оцінки у балах можна робити висновок, що найкращими органолептичними показниками характеризується зразок консервів ТМ «Чумак»-29,6 балів. Дещо менше балів набрали зразки кукурудзи TM «Щедрий Пан» та TM «RIO»-26,2 та 21,2 бали відповідно. Найменшу кількість балів набрав зразок кукурудзи консервованої виробництва ТМ «Гурман» - 12,2 бали із 30 можливих.

Під час вивчення фізико-хімічних показників кукурудзи консервованої було встановлено масову частку зерен до маси нетто консервів та масову частку хлоридів у зразках досліджуваних консервів. Результати визначення наведені у табл. 3 .

Наведені у табл. 3 дані свідчать про те, що за вмістом зерен у консервах зразки кукурудзи торгових марок «Щедрий Пан» та «Гурман» не відповідають вимогам ДСТУ 7164:2010, адже ї вміст менший, ніж 60\%. За вмістом хлоридів вимогам ДСТУ відповідає лише кукурудза ТМ «Чумак».

Таблиця 3

Фізико-хімічні показники якості зразків кукурудзи консервованої

\begin{tabular}{|c|c|c|c|c|c|}
\hline \multirow{2}{*}{ Показник } & \multirow{2}{*}{$\begin{array}{l}\text { За ДСТУ } \\
\text { 7164:2010 }\end{array}$} & \multicolumn{4}{|c|}{ Зразки консервів } \\
\hline & & ТМ «Щедрий Пан» & $\mathrm{TM} \ll \mathrm{RIO} »$ & ТМ «Гурман» & ТМ «Чумак» \\
\hline $\begin{array}{l}\text { Масова частка зерен } \\
\text { від маси нетто } \\
\text { консервів, вказаної на } \\
\text { етикетці, \%, не менше }\end{array}$ & 60,0 & 58,9 & 60,5 & 55,3 & 66,7 \\
\hline $\begin{array}{l}\text { Масова частка } \\
\text { хлоридів, \% }\end{array}$ & $0,8-1,5$ & 1,7 & 1,8 & 2,2 & 1,3 \\
\hline
\end{tabular}


3 результатом комплексної оцінки якості обраних зразків консервованої кукурудзи, можна зробити загальний висновок, що продукт ТМ «Чумак» демонструє високі органолептичні та фізикхімічні показники якості та відповідає вимогам, що викладені в ДСТУ 7164:2010.

\section{Висновки}

Здійснено технологічну експертизу та оцінку якості зразків кукурудзи консервованої виробництва торгових марок «Щедрий Пан», «RIO», «Гурман» та «Чумак». Шляхом органолептичного дослідження встановлено, що найкращими органолептичними показниками за запахом, кольором, смаком, зовнішнім виглядом, цілісністю зерен, кольором заливи характеризується зразок консервів ТМ «Чумак». Визначення фізико-хімічних характеристик зразків консервованої кукурудзи свідчить, що серед досліджуваних консервів вимогам ДСТУ 7164:2010 відповідає продукт ТМ «Чумак» за показниками масової частки зерен від маси нетто консервів та масової частки хлоридів.

\section{Список використаної літератури}

1. Лозинська Т.М. Національний продовольчий ринок в умовах глобалізації: монографія. Харків: Вид-во ХарРІНАДУ «Магістр», 2007. - 272 с.

2. Рослинництво України 2018. Статистичний збірник Державної служби статистики України, 2019 Режим доступу: http://www.ukrstat.gov.ua/.

3. Кукурудза. Вирощування, збирання, консервування і використання / Під загальною редакцією Д. Шпаара. - К.: Альфа-стевія ЛТД - 2009. - 396 с.

4. Фан-Юнг А.Ф., Флауменбаум Б.Л., Изотов А.К. Технология консервирования плодов и овощей. - М.: Пищевая промышленность, 1969. - 608 с.

5. Щеглов Н.Г. Технология консервирования плодов и овощей. - М.: Палеотип, 2002. -380 с.

6. ДСТУ 7164:2010 «Кукурудза цукрова консервована. Технічні умови». - К.: Держспоживстандарт України, 2011. - 12 с.

7. ГОСТ 8756.1-2017. Продукты переработки фруктов, овощей и грибов. Методы определения органолептических показателей, массовой доли составных частей, массы нетто или объема. - М.: Стандартинформ, 2019. - 17 с.

8. ГОСТ 26186-84. Продукты переработки плодов и овощей, консервы мясные и мясорастительные. Методы определения хлоридов. - М.: Стандартимформ, 2010. - 10 с.

\section{References}

1. Lozyns'ka T.M. Natsional'nyy prodovol'chyy rynok $\mathrm{v}$ umovakh hlobalizatsiyi: monohrafiya. Kharkiv: Vyd-vo KharRINADU «Mahistr», 2007. -272 p.

2. Roslynnytstvo Ukrayiny 2018. Statystychnyy zbirnyk Derzhavnoyi sluzhby statystyky Ukrayiny, 2019 Rezhym dostupu: http://www.ukrstat.gov.ua/.

3. Kukurudza. Vyroshchuvannya, zbyrannya, konservuvannya i vykorystannya / Pid zahal'noyu redaktsiyeyu D. Shpaara. - Kyiv.: Al'fa-steviya LTD - 2009. - 396 p.

4. Fan-Yunh A.F., Flaumenbaum B.L., Yzotov A.K. Tekhnolohyya konservyrovanyya plodov y ovoshchey. - M.: Pyshchevaya promyshlennost', 1969. -608 p.

5. Shchehlov N.H. Tekhnolohyya konservyrovanyya plodov y ovoshchey. - Mockva.: Paleotyp, 2002. $380 \mathrm{~s}$.

6. DSTU 7164:2010 «Kukurudza tsukrova konservovana. Tekhnichni umovy». - Kyiv: Derzhspozhyvstandart Ukrayiny, 2011. -12 p.

7. HOST 8756.1-2017. Produkty pererabotky fruktov, ovoshchey y hrybov. Metody opredelenyya orhanoleptycheskykh pokazateley, massovoy doly sostavnykh chastey, massy netto yly ob"ema. - Mockva.: Standartynform, 2019. $-17 \mathrm{p}$.

8. HOST 26186-84. Produkty pererabotky plodov y ovoshchey, konservy myasnye y myasorastytel'nye. Metody opredelenyya khlorydov. - M.: Standartymform, 2010. - 10 p. 